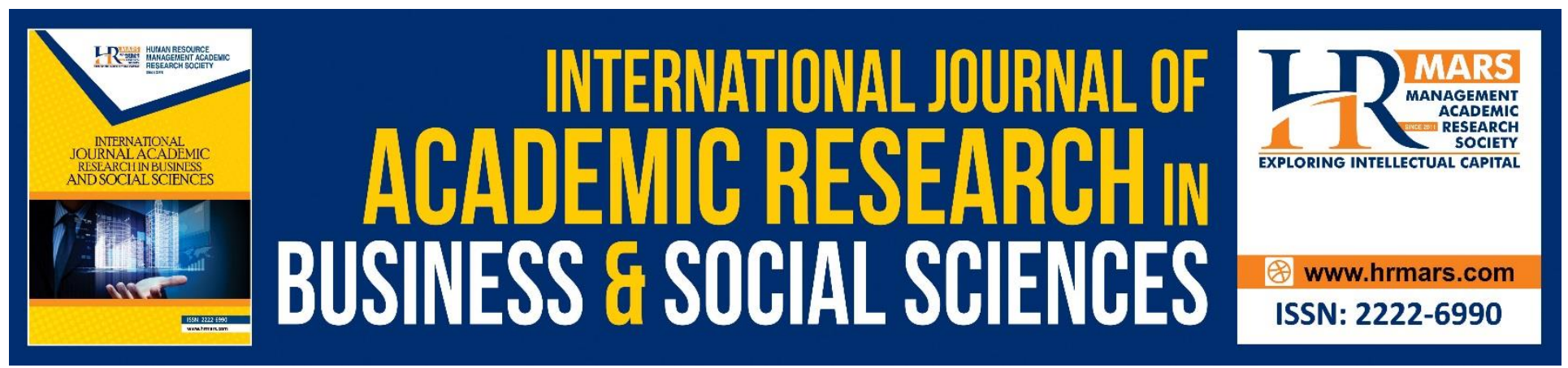

\title{
The Effect of Personality Traits (Big-Five), Materialism and Stress on Malaysian Generation Y Compulsive Buying Behaviour
}

Fatin Farwizah Mat Rahim, Husniyah Abd Rahim

To Link this Article: http://dx.doi.org/10.6007/IJARBSS/v8-i7/4346

DOI: $10.6007 /$ IJARBSS/v8-i7/4346

Received: 06 July 2018, Revised: 30 July 2018, Accepted: 01 August 2018

Published Online: 05 August 2018

In-Text Citation: (Rahim \& Rahim, 2018)

To Cite this Article: Rahim, F. F. M., \& Rahim, H. A. (2018). The Effect of Personality Traits (Big-Five), Materialism and Stress on Malaysian Generation Y Compulsive Buying Behaviour. International Journal of Academic Research in Business and Social Sciences, 8(7), 349-362.

Copyright: (C) 2018 The Author(s)

Published by Human Resource Management Academic Research Society (www.hrmars.com)

This article is published under the Creative Commons Attribution (CC BY 4.0) license. Anyone may reproduce, distribute, translate and create derivative works of this article (for both commercial and non-commercial purposes), subject to full attribution to the original publication and authors. The full terms of this license may be seen at: $\underline{\text { http://creativecommons.org/licences/by/4.0/legalcode }}$

Vol. 8, No. 7, July 2018, Pg. 349 - 362

http://hrmars.com/index.php/pages/detail/IJARBSS

JOURNAL HOMEPAGE

Full Terms \& Conditions of access and use can be found at http://hrmars.com/index.php/pages/detail/publication-ethics 


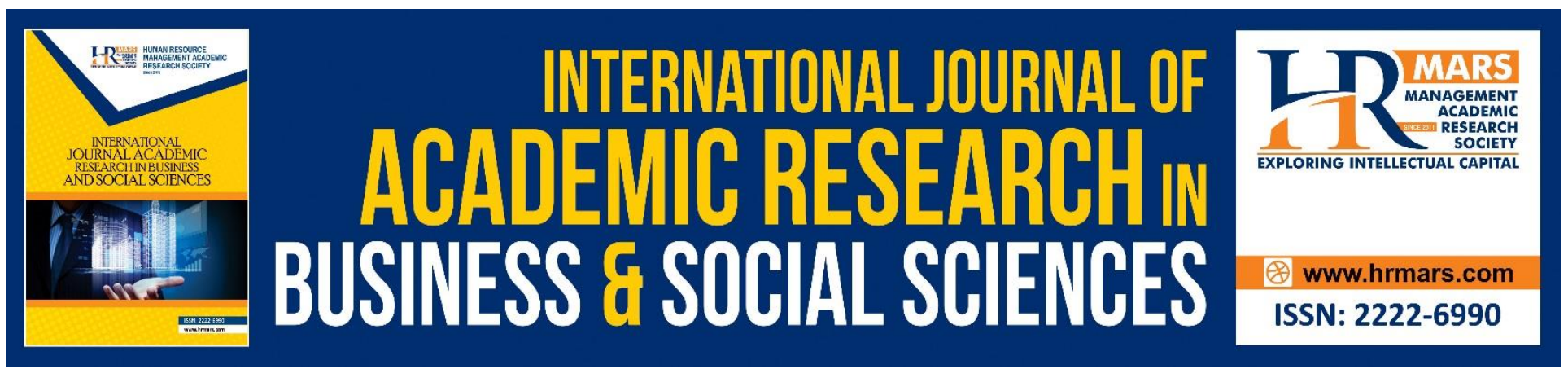

\title{
The Effect of Personality Traits (Big-Five), Materialism and Stress on Malaysian Generation Y Compulsive Buying Behaviour
}

\author{
Fatin Farwizah Mat Rahim, Husniyah Abd Rahim \\ Department of Resource Management and Consumer Studies, Faculty of Human Ecology, Universiti \\ Putra Malaysia.
}

\section{Abstract}

The continuous activities of productions and consumptions can help the economic growth of a country. However, excessive spending by consumers who want to keep up with various productions of goods and services can eventually be harmful as for their financial and psychological well-being. This study aims to determine the effect of personality traits (Big-Five), materialism and stress on Malaysian generation $Y$ compulsive buying behaviour. Self-administered questionnaires were distributed to the respondents which were drawn using systematic random sampling. The findings demonstrated that agreeableness, neuroticism and materialism have significant effects on Malaysian generation $\mathrm{Y}$ compulsive buying behaviour, where materialism is the strongest predictor among all variables tested. The results indicated that individuals' compulsive buying behaviour in this context of study was mainly affected by their activities to engage in the development and maintenance of self through the acquisition and use of products and services that are believed to be able to provide desirable symbolic value. This study is expected to contribute in the field of consumer behaviour and Malaysian generation $Y$ literature as it attempts to integrate three important variables that can affect compulsive buying behaviour which is personality traits (Big-Five), materialism and stress.

Keywords: Compulsive Buying Behaviour, Generation Y, Materialism, Personality Traits, Stress

\section{Introduction}

According to the Malaysian Association of Shopping and High-Rise Complex Management, the supply of shopping malls in Malaysia can be considered as a massive one. It is expected that about 17 million square feet of land in the Klang Valley will be reserved for shopping space up until the year of 2019. The Henry Butcher Retail managing director, Tan Hai Hsin said that in the year of 2015, there were 927 shopping centres in Malaysia and it is also expected that another 102 shopping centres will be completed in the year of 2018. The existence of various shopping centres in Malaysia with different types of attractions offered can trigger consumers into purchasing activities. According to Osman, Ong, Othman and Khong (2014), the atmospheric cues present inside a shopping mall itself can influence consumers' in-store behaviour in terms of money and time spent, also the intention to revisit the shopping mall. In addition to that, Hussain and Ali (2015) found that the scent, lighting and 
INTERNATIONAL JOURNAL OF ACADEMIC RESEARCH IN BUSINESS AND SOCIAL SCIENCES Vol. 8, No. 7, July 2018, E-ISSN: 2222-6990 @ 2018 HRMARS

product display inside a mall affect consumers' purchase intention and eventually trigger the purchasing activities of compulsive shoppers.

Compulsive shopping behaviour or compulsive buying has been recognised 100 years ago by a German psychiatrist named Emil Kraepelin. Back then, the term used was Oniomania which means as an obsessive or uncontrollable urge to buy things. The term is then revised and eventually known as compulsive buying. Compulsive buying is an obsession with buying and shopping by frequent buying episodes or appetency to buy that are experienced as irresistible and senseless (Black, Shaw, \& Blum, 2010). The shopping episodes will give temporary relief and pleasure but eventually turns out to be as guilt and regret due to the improper spending behaviour.

A research from the Stanford University School of Medicine lead by Lorrin Koran in 2006 found that women and men who are compulsive buyers had equally close in numbers. It was reported that $6 \%$ of women and $5.5 \%$ of men had consistent symptoms related to the compulsive buying behaviour (Koran, Faber, Aboujaoude, Large, \& Serpe, 2006). In addition to that, they also found that compulsive buyers are mostly younger in age with income below USD50,000. As for the Malaysian context, generation $\mathrm{Y}$ is the most suitable population to further investigate this issue as accompanied by the triggers from national and international brand outlets and with diverse product choices offered from retailers, consumers especially the largest market segment consumer, generation $Y$, prone to fail in planning their finances wisely. In nature, generation $Y$ is the main target consumer market because they are the generation that mostly starts working and experience managing their own money for the first time. They have the highest contribution to demand goods and they are the generation that lives and keeps on adapting to fast-paced changes in technology. Thus, people especially generation $Y$ will be focusing more on the material aspect of lives rather than spiritual and emotional aspect. As a result, they will be cumulated with debt to satisfy their desire to buy and own goods and services offered. This problem will lead into a much worse state in which individual can be declared with bankruptcy resulting from cumulating mountains of debt that is caused by compulsive buying behaviour (Zamzamin, Jaini, \& Mat Zaib, 2015).

The globalisation also has impacted the society. People becoming more stressful and willing to do anything to keep at the same pace with current social trends. The existence of social media such as YouTube, Instagram and Facebook have created insecurity among society especially among generation $\mathrm{Y}$ as they will keep on comparing their current state of lives with others that have better lives. The insecurities will then develop into behavioural problems such as compulsive buying behaviour. Consequently, this problem may lead to some serious mental issues. According to the Illinois Institute for Addiction Recovery, problems that can arise resulting from compulsive buying behaviour are depression, anxiety, work and family problem.

In response to this situation, this study will emphasise three factors which are personality traits (Big-Five traits), materialism and stress that can affect consumers' behaviour which is the compulsive buying behaviour in Malaysia, especially among the generation Y. Accordingly, the aim of this study is to determine the effect of personality traits (Big-Five traits), materialism and stress on Malaysian generation $\mathrm{Y}$ compulsive buying behaviour. Thus, it is expected that this study will contribute significantly in emphasising the term of compulsive buying behaviour in the context of Malaysian Generation $Y$ population. It is also expected that this study will help Generation $Y$ consumers in improving their financial education by looking at the internal factors that can cause them to be compulsive in buying. 
INTERNATIONAL JOURNAL OF ACADEMIC RESEARCH IN BUSINESS AND SOCIAL SCIENCES

Vol. 8, No. 7, July 2018, E-ISSN: 2222-6990 @ 2018 HRMARS

\section{Literature Review \\ Related Theories}

The Escape Theory proposed by Ronald J. Faber in 2006 is used to explain human behaviours such as suicide, compulsive buying, and binge eating. This theory proposed that there are reasons of why compulsive buyers engaged in the negative behaviour. He explained that some people found that self-awareness is something painful. Individuals have very high expectation that they are unable to meet and will eventually lead to depression, feeling of failures and anxiety. These individuals will seek ways of lifting the negative thoughts by engaging themselves with immediate, concrete and low-level activities. The environment from those activities is seen to be able to block the frustration of daily life. This theory also states that during those activities, individuals will not consider for the long-range consequences of the actions and they are also not recognised the implausibility of fanciful thoughts which makes them become irrational in actions (Ridgway, Kukar-Kinney, \& Monroe, 2006).

As applied to this study, this theory holds that it is expected that personality traits, especially the neuroticism dimension and stress will influence compulsive buying behaviour because it has the characteristics that account for an individual to be a compulsive buyer. The theory shows that compulsive buyers experience negative and painful self-awareness, perfectionists and hold themselves at very high standards, and perceived failure and other negative feelings as triggers for compulsive buying behaviour. Individuals with high in neuroticism trait have the same core elements in which they are prone to experience psychological distress, anxiety and worry. These characteristics also can be related with the definition of stress proposed by Lazarus and Folkman (1984) where it is an environment judged by individuals as threatening and overwhelming to their well-being and these individuals will seek ways to avoid the threat.

The Escape Theory mainly explains excessive human behaviour. On the other hand, the Theory of Leisure Class which was first proposed by American sociologist and economist, Thorstein Veblen in 1899, argues that under the barbarian practice, social honour is evaluated based on the tangible evidence of great abilities and skills possessed by an individual. In an earlier era, private property is the basis of self-esteem. The leisure class is also known as those who are ranked with the highest position in society. The lower ranks will be much admired with the leisure class's acquisition of power, goods and services. As a consequence, individuals will put very much reliability in possessing tangible evidence as a mean to be recognised by society as well (Veblen, 1994).

The term proposed by Veblen is conspicuous consumption in which to emphasise the act of purchasing goods and services, not to survive but to identify oneself with others as possessing superior wealth and social standing. This definition is seen as related with the definition of materialism by Shrum, Wong, Arif, Chugani, Gunz, Lowrey, Nairn, Pandelaere, Ross, Ruvio, Scott and Sundie (2013) in which it is the extent to which individuals seek to engage in the development and maintenance of self through the acquisition and use of products, services, experiences or relationship that can provide a desirable symbolic value. As applied to this study, this theory will serve as a basis in explaining the influence of materialism with compulsive buying because it posits similar characteristics with materialism such as purchasing for the sake of recognition.

\section{Compulsive Buying Behaviour}

Compulsive buying behaviour is defined as the urge to buy that is impossible to resist, individuals' uncontrollable buying behaviour and excessive buying despite the negative consequences in their personal, social and financial health (Dittmar, 2004). Individuals with compulsive buying behaviour perceived buying episodes as a mean of escaping from anxiety, depression, anger, pain or stress 
INTERNATIONAL JOURNAL OF ACADEMIC RESEARCH IN BUSINESS AND SOCIAL SCIENCES Vol. 8, No. 7, July 2018, E-ISSN: 2222-6990 @ 2018 HRMARS

(Miltenberger, Redlin, Crosby, Stickney, Mitchell, Wonderlich, Faber, \& Smyth, 2003; O’Guinn \& Faber, 1989). These individuals are also known as individuals that are primarily interested in the activity of browsing, choosing, and shopping but rarely or never using the items bought (Muller, Mitchell, \& Zwann, 2015).

Boundy (2000) proposed that children will follow the same behaviour as their parents who display compulsive buying behaviour. Today, parents tend to reward their children with material things and the children, as they grow up, will develop the same pattern of self-rewarding with goods when they feel down or stress. The buying episodes will usually be accompanied by the feel of pleasure and relief but guilt and depression afterwards. The lingering negative feelings are resulted from buying things that are not needed or too expensive for the individual (Lawrence, Ciorciari, \& Kyrios, 2014).

Recent researches which investigate the effect of depression, materialism and excessive use of the internet on compulsive buying behaviour found both depression and materialism were the significant factors that affect compulsive buying behaviour (Mueller, Mitchell, Peterson, Faber, Steffen, Crosby, \& Claes, 2011; Omar, Wel, Alam, \& Nazri, 2015). Quoquab, Yasin and Banu (2013) have studied the compulsive buying behaviour among Malaysian citizens and the result revealed that perceived social image can affect compulsive buying behaviour directly and in accordance with the result from Mueller et al. (2011), the factor of materialism also affects compulsive buying behaviour directly and it was partially mediated the relationship between perceived social image and compulsive buying.

\section{Personality Traits (Big-Five)}

Costa and McCrae (1992) have proposed the five-factor model that is found to be a strongly grounded research in explaining the different traits in an individual. The five-factor model consists of five dimensions namely extraversion, neuroticism, agreeableness, openness to experience, and conscientiousness.

Extraversion is known as individuals with traits such as sociable, talkative, assertive, ambitious and active (Shahjehan, Qureshi, Zeb, \& Saifullah, 2012). Cavanaugh and Blanchard-Fields (2011) have specified that extravert individuals prefer to be in a stimulating environment rather than the passive environment. Neuroticism is a trait of individuals that are prone to experience psychological distress, anxiety and worry. They always feel insecure and have emotional instability (Gohary \& Hanzaee, 2014). According to Cavanaugh and Blanchard-Fields (2011), these individuals tend to do things in excess such as overspending, overeating and prone to get panic and have a low ability to deal with any stressful events. Openness to experience also known as intellect domain makes the individual that possesses this trait to be imaginative and sensitive to arts. They are also intellectually curious, flexible to changes and have such a complex emotional life (Gohary \& Hanzaee, 2014). According to Milfont and Sibley (2012), individuals whose score high in agreeableness are compliant, pleasant, cooperative and strongly cared about the well-being of family members and friends. They also tend to trust rather than doubt and will not have strong negative emotion as compared with individuals with low agreeableness. The last trait domain of personality is conscientiousness. They have a strong internal locus of control and are also known as reliable, punctual, self-discipline, neat and competent (Maltby, Day, \& Macaskill, 2010). Conscientiousness individuals can control their impulsivity and prefer delayed gratification (Joshanloo, Rastegar, \& Bakhshi, 2012).

Personality traits are proven by many researchers to be one of the main factors that can affect compulsive buying behaviour. It is reported that among the five personality traits, Neuroticism trait 
INTERNATIONAL JOURNAL OF ACADEMIC RESEARCH IN BUSINESS AND SOCIAL SCIENCES Vol. 8, No. 7, July 2018, E-ISSN: 2222-6990 @ 2018 HRMARS

gives the most significant relationship with the individual being a compulsive buyer (Shahjehan et al., 2012). An individual with emotion instabilities such as depression, anxiety, moodiness and irritability have high tendency to exert compulsive buying behaviour. Other than that, they also tested personality traits (Big-Five traits) with impulsive buying to investigate the impact of it on buying behaviour. It was found that each of the Big-Five traits was positively affected impulsive buying.

Based on the findings from research done by Otero-Lopez and Villardefrancos (2013), it is concluded that neuroticism, extraversion, agreeableness and openness affect compulsive buying behaviour where neuroticism is the most significant trait. The findings also prove that conscientiousness is the only trait that shows a negative relationship with compulsive buying behaviour. In another research which investigates the relationship between Big-Five personality traits with shopping motivation found that conscientiousness, neuroticism and openness as the significant factors for compulsive buying, impulsive buying and utilitarian shopping values (Gohary \& Hanzaee, 2014).

\section{Materialism}

Shrum et al. (2013) suggested that materialism is the degree where individuals engage in the development and maintenance of self, through the possession of products, services and experiences. Materialism acts as an identity builder for individuals. However, there are growing concerns among researchers that materialism can give more negative consequences to individuals such as growing amount of debt, depression and greed (Tsang, Carpenter, Roberts, Frisch \& Carlisle, 2014). Materialists put acquisitions of goods as their priority in life and they perceive it as a source of success and happiness (Richins \& Dawson, 1992). The materialism level also differs across generations. The materialism level continuously increasing from the Baby Boomers generation, Generation $\mathrm{X}$ and Generation $Y$ because of the advanced technology and individuals' exposure to the global world (Twenge \& Kasser, 2013).

Researchers have found that materialism has a significant impact on compulsive buying. According to Bindah and Othman (2012), social interaction of consumers acts as a moderating variable for consumers having high materialistic values that will eventually lead to compulsive buying behaviour. The higher the interaction, the higher the materialistic values, thus makes the compulsive buying tendencies higher. Materialism also can affect compulsive buying behaviour when consumer especially young consumer perceived success, acknowledgement and happiness from the acquisition of goods and services (Rasool, Kiyani, Khattak, Ahmed, \& Ahmed, 2012). Omar et al. (2015) also consistently found that materialism does significantly affect compulsive buying where young consumers have the highest tendency towards that. In a similar vein, Quoquab et al. (2013) also found that materialism is direct, positively and significantly affect compulsive buying behaviour in which individuals that have high self-awareness tend to value materialism as a mean to improve their social image. This tendency is shown by young consumers that are considered as sensitive towards the social image, thus tend to exert high materialistic values.

\section{Stress}

Stress is a mismatch between demand and the ability to cope with the demand (Duffy, Cunningham, \& Moore, 2005). Lazarus and Folkman (1984) first proposed stress as the relationship between individual and environment in which the individual perceived the environment as a threat. The degree of stress varied from one individual to another according to the intensity of the threat perceived by the individuals. According to Veena and Shastri (2016), stress can be helpful and 
INTERNATIONAL JOURNAL OF ACADEMIC RESEARCH IN BUSINESS AND SOCIAL SCIENCES Vol. 8, No. 7, July 2018, E-ISSN: 2222-6990 @ 2018 HRMARS

stimulating if it is able to drive individuals in achieving something good, on the opposite side, it can be bad or negative if individuals perceived it as excessive and threatening until it can affect their physical, mental and emotional well-being.

Based on a recent study by Durante and Laran (2016) which emphasised on the effect of stress on consumer saving and spending, they proposed that consumers respond to stress in two different ways depending on the nature of the stress and the way they perceived the stress. Firstly, consumers that prefer to save rather than spend or only buy necessities if encountered with a stressful environment. Secondly, consumers that prefer to spend rather than save if encountered in a stressful environment. This pattern depicts that stress does not give singular effect on consumers' behaviour instead, it is depending on the consumers' perception in controlling their environment. Past researchers have consistently found that respondents which scored high in compulsive buying scale also reported as having high score on perceived stress scale on different background of population (Harvanko, Lust, Odlaug, Schreiber, Derbyshire, Christenson, \& Grant, 2013; Pidgeon, Bottomley, \& Bannatyne,2015; Roberts \& Roberts, 2012).

\section{Methodology}

This study used a correlational research design in which a quantitative, cross-sectional survey was conducted. The survey was given to the sample group of Malaysian Generation Y population by using simple random sampling. According to the report on household expenditure survey 2016 done by the Department of Statistics Malaysia, Wilayah Persekutuan Putrajaya, Wilayah Persekutuan Kuala Lumpur and Selangor are recorded having the highest mean monthly household consumption expenditure as compared with another state in Malaysia, thus, Klang Valley was chosen as the area to conduct this study. Two public universities within the Klang Valley area were randomly chosen. As a result, respondents for this study was among students from Universiti Putra Malaysia (UPM) and Universiti Malaya (UM). University students are qualified to be respondents for this study because most of them were born within the 1980's to early 1990's cohort and this age cohort is known as the Generation Y since they were born between the year of 1980 to 1999 (Gurau, 2012).

According to the Ministry of Higher Education Malaysia (2016), there are 1.2 million of Malaysian students who are currently studying in the Higher Learning Institutions. Taking the updated statistics into account, with $90 \%$ of confidence level, the minimum sample size for this study was 99 respondents. Since there are seven independent variables used in this study, a minimum of 20 respondents should be considered for each variable, thus makes up the total of 140 respondents are selected to be the sample for this study (Pallant, 2011). Hence, fulfilling the minimum requirement for the number of sample used in this study.

\section{Instrument and Measurement}

Respondents were given a set of questionnaires that assessed their personality traits (Big-Five traits), materialism, stress and compulsive buying behaviour levels. The Mini-IPIP scale developed by Baldasaro, Shanahan and Bauer (2013) was used in the questionnaire to assess the Big Five factors of personality traits of the respondents. The reliability was found to be acceptable where the Cronbach's alpha for each factor scale shows result higher than 0.6. Material Values Scale (MVS) was used to assess the level of materialism of the respondents. It is a short version scale-revised by Richins (2004) which consists of a nine-item scale instead of the original 18-item scale developed by Richins and Dawson (1992). The nine-item scale gives Cronbach's alpha of 0.84. Perceived Stress Scale 10 (PSS10) was used to determine respondent's stress level by assessing their perceived stressful events or 
INTERNATIONAL JOURNAL OF ACADEMIC RESEARCH IN BUSINESS AND SOCIAL SCIENCES

Vol. 8, No. 7, July 2018, E-ISSN: 2222-6990 @ 2018 HRMARS

experienced over the previous months. This PSS-10 scale was developed by Al-Dubai, Al-Shagga, Rampal and Sulaiman (2012). The Cronbach's alpha yields value of 0.78 for the total scale. The compulsive buying behaviour was assessed by using the Edwards Compulsive Buying Scale-Revised (ECB-R) from Maraz, Eisinger, Hende, Urban, Paksi, Kun, Kokonyei, Griffiths and Demetrovics (2015). The Cronbach's alpha for the whole scale was 0.87 . All the items were measured using a five-point Likert scale.

\section{Result and Discussion}

\section{Demographic Profile of the Respondents}

The age was divided into two categories which are early adulthood ( $18-23$ years old) and adulthood (24 - 29 years old). Most of the respondents fall under the early adulthood age category which has 114 respondents (81\%). Meanwhile, another 26 respondents (19\%) came from the adulthood age category. Malays consist of 96 respondents (68\%) and Chinese makes up the second largest of the race portion which has 33 respondents (24\%). Most of the respondents currently pursue a bachelor's degree with 108 respondents (77\%).

Table 1: Demographic Profile of Respondents

\begin{tabular}{ll}
\hline Variable & Frequency $(\mathrm{n})(\mathrm{N}=140)$ \\
\hline Age (years old) & $114(81 \%)$ \\
$18-23$ & $26(19 \%)$ \\
$24-29$ & \\
Gender & $70(50 \%)$ \\
Male & $70(50 \%)$ \\
Female & \\
Race & $96(68 \%)$ \\
Malay & $33(24 \%)$ \\
Chinese & $4(3 \%)$ \\
Indian & $7(5 \%)$ \\
Others & \\
& \\
Educational Level & $108(77 \%)$ \\
Bachelor's Degree & $19(14 \%)$ \\
Foundation & $2(1 \%)$ \\
Diploma & $9(7 \%)$ \\
Master & $2(1 \%)$ \\
Doctor of Philosophy (PhD) &
\end{tabular}

\section{Levels of Materialism, Stress and Compulsive Buying Behaviour}

One of the objectives of this study was to determine the levels of materialism, stress and compulsive buying behaviour of the respondents. The scores for materialism were divided into three levels which are low (10-23), moderate (24-37) and high (38-50). The result indicates that more than half of the respondents (75.0\%) scored with a moderate level of materialism which might be due from the 60.7 
INTERNATIONAL JOURNAL OF ACADEMIC RESEARCH IN BUSINESS AND SOCIAL SCIENCES Vol. 8, No. 7, July 2018, E-ISSN: 2222-6990 @ 2018 HRMARS

percent of the respondents agreed that they try to keep their life simple as far as possessions are concerned. As for the stress levels, the scores were also divided into three levels similar to materialism. Majority of the respondents (87.1\%) scored with a moderate level of stress. The highest percentage of score that the respondents gave for each item falls on scale number three which is the middle scale, ("sometimes in the last month") they did trigger with any stressful events, thus it contributed to a total of 87.1 percent of the respondents with a moderate level of stress. Meanwhile, as for the score of compulsive buying behaviour, the scores were divided into three levels which are low (16-36), moderate (37-57) and high (58-80). Most of the respondents surveyed scored with a moderate level of compulsive buying behaviour (65.7\%).

In general, respondents of this study depict a moderate level of materialism, stress and compulsive buying behaviour. It can be concluded that the respondents showed the same moderate level across the variables because of their status as students which does not yet have fixed income and does not have an excessive amount of work-related stress. Usually, students with a tertiary level of education are sponsored by either government or private organisation, thus they need to manage and control their expenses with a tight budget, hence making them able to control their materialistic value, stress and compulsive buying behaviour at a moderate level.

\section{The Relationship of Personality Traits (Big-Five), Materialism and Stress with Compulsive Buying Behaviour}

Table 2 presents the correlation between personality traits (Big-Five), materialism and stress with compulsive buying behaviour. Openness to experience personality dimension has p-value 0.280 while $r$-value -0.092, meaning that there is no significant relationship between openness to experience with compulsive buying behaviour. As can be seen, the conscientiousness personality dimension also yields the same result where the $p$-value and $r$-value are 0.800 and -0.022 respectively. $P$-value and $r$-value for agreeableness personality dimension are 0.476 and -0.061 respectively, meaning that there is no significant relationship between agreeableness and compulsive buying behaviour.

On the other hand, extraversion personality dimension shows $p$-value with 0.043 and $r$-value with 0.171 , meaning that there is a significant relationship between extraversion with compulsive buying behaviour where the correlation is positive but very weak. In addition, the neuroticism personality dimension has $p$-value 0.000 and $r$-value 0.379 indicates that there is a weak but significant relationship between neuroticism and compulsive buying behaviour and the correlation is positive to each other. Stress and materialism also depict the same results where the $p$-value is 0.000 for both and r-value is 0.360 and 0.632 respectively. As a result, stress shows a positive and weak relationship with compulsive buying behaviour, meanwhile materialism shows a positive and strong relationship with compulsive buying behaviour. 
INTERNATIONAL JOURNAL OF ACADEMIC RESEARCH IN BUSINESS AND SOCIAL SCIENCES Vol. 8, No. 7, July 2018, E-ISSN: 2222-6990 @ 2018 HRMARS

Table 2: The Relationship of Personality Traits (Big-Five), Materialism and Stress with Compulsive Buying Behaviour

\begin{tabular}{lll}
\hline Variables & $\begin{array}{l}\text { Pearson Correlation } \\
(r \text {-value })\end{array}$ & Sig. (2-tailed) (p-value) \\
\hline Personality Traits & & \\
- Openness to experience & -0.092 & 0.280 \\
- Conscientiousness & -0.022 & 0.800 \\
- Extraversion & 0.171 & $0.043^{* *}$ \\
- Agreeableness & -0.061 & 0.476 \\
- Neuroticism & 0.379 & $0.000^{* *}$ \\
Materialism & 0.632 & $0.000^{* *}$ \\
Stress & 0.360 & $0.000^{* *}$ \\
\hline
\end{tabular}

Note: ${ }^{* *} \mathrm{p} \leq 0.05$

\section{Multiple Regression Analysis}

This analysis provides means for objectively assessing the degree of relationship between the personality traits (Big-Five), materialism and stress on the compulsive buying behaviour.

Table 3: Multiple Regressions for Compulsive Buying Behaviour

\begin{tabular}{lllll}
\hline Variable & $\mathrm{B}$ & $\mathrm{Beta}$ & $\mathrm{t}$ & Sig. (p-value) \\
\hline (Constant) & -3.186 & & -0.318 & 0.751 \\
Openness to Experience & -0.140 & -0.033 & -0.463 & 0.644 \\
Conscientiousness & -0.439 & -0.099 & -1.634 & 0.105 \\
Extraversion & 0.087 & 0.028 & 0.388 & 0.698 \\
Agreeableness & -0.993 & -0.199 & -2.983 & $0.003^{* *}$ \\
Neuroticism & 1.275 & 0.243 & 3.579 & $0.000^{* *}$ \\
Materialism & 1.151 & 0.620 & 9.525 & $0.000^{* *}$ \\
Stress & 0.166 & 0.074 & 1.005 & 0.317 \\
\hline
\end{tabular}

Note: ${ }^{* *} \mathrm{p} \leq 0.01 ; \mathrm{R}^{2}=0.555 ;$ Adjusted $\mathrm{R}^{2}=0.528 ; \mathrm{F}=20.405$;

Standard multiple regression was used to assess variable which can be highly significant predictor for Malaysian Generation $Y$ compulsive buying behaviour. Preliminary analyses were conducted to ensure all the assumptions for normality, linearity and multicollinearity are met. The multiple correlation square $\left(R^{2}=0.555\right)$ depicts more than half $(55.5 \%)$ of the variance in the compulsive buying behaviour is explained by the model. In addition to that, the ANOVA test shows significant influence between both independent variables and dependent variables $(F=20.405 ; p<0.01)$, hence it confirms that the model is valid to be further assessed. Agreeableness trait, neuroticism and materialism are seen to have significant influences on compulsive buying behaviour. Neuroticism and materialism are both having a positive influence on compulsive buying behaviour. The result is true as individuals with neuroticism personality traits and materialistic individuals also have high tendencies in buying compulsively. The findings are also supporting previous researches' findings indicating the same trend (Bindah \& Othman, 2012; Omar et al., 2015; Rasool et al., 2012; Shahjehan et al., 2012). On the other hand, the agreeableness personality traits have a negative influence on 
INTERNATIONAL JOURNAL OF ACADEMIC RESEARCH IN BUSINESS AND SOCIAL SCIENCES Vol. 8, No. 7, July 2018, E-ISSN: 2222-6990 @ 2018 HRMARS

compulsive buying behaviour. It is the opposite to the result of past researches which discovered that agreeableness trait is among one of the four traits that can influence compulsive buying behaviour (Mueller et al., 2011; Shahjehan et al., 2012; Shehzadi, Ahmad-ur-Rehman, Cheema, \& Ahkam, 2016). The negative influence of agreeableness trait of this study might be caused individuals with agreeableness trait tend to trust rather than doubt and will not have strong negative emotion as compared with individuals with low agreeableness which makes them having lower tendencies for buying compulsively. In comparing all three significant variables, the relative strength of the positive influence of neuroticism trait $(\beta=0.243 ; p<0.01)$ is weak, meanwhile for materialism, the positive relative strength is strong $(\beta=0.620 ; p<0.01)$ with compulsive buying behaviour. On the other hand, agreeableness trait $(\beta=0.199 ; p<0.01)$ has a very weak negative influence with compulsive buying behaviour.

\section{Conclusion and Implication}

This study was conducted to determine the effect of personality traits (Big-Five), materialism and stress on Malaysian generation $Y$ compulsive buying behaviour. The major findings of this study revealed that agreeableness, neuroticism and materialism were significantly affect Malaysian generation $Y$ compulsive buying behaviour where materialism is the most significant predictor. These findings supported the Escape Theory which stated that individuals with high negative emotions as those with high in neuroticism using compulsive buying as an escape medium from all the daily frustration events that they have faced. The finding of this study also supported the Theory of Leisure Class which stated that individuals purchase goods and services, not for the basic needs but to identify oneself with others as possessing superior wealth and social standing. This can be proven by present study when half of the respondents agreed that their life would be much better if they could own certain things they do not have, and they also agreed that it bother them sometimes when they cannot afford to buy all the things they like instead of the things that they need.

The framework of this study is concerned with personality traits (Big-Five), materialism and stress as determinants that can affect Malaysian generation $Y$ compulsive buying behaviour. As far as this study acknowledged, no past research has investigated compulsive buying behaviour by using these three variables simultaneously. Other than that, previous research mostly focusing on compulsive buying behaviour in developed countries as in the United States and less emphasis on the developing countries such as Malaysia. Therefore, the findings of the present study able to contribute and filled the potential gap in the research of consumer behaviour particularly on compulsive buying behaviour on Malaysian generation $Y$ context of population.

This study can be used to educate consumers in making them explicitly aware of their individual self and the triggers that might cause them to develop into compulsive buying behaviours such as their own personality traits, materialistic values and stress, thus, they will be able to control it and by time, able to improve themselves. On top of that, governmental and non-governmental agencies can join forces to educate consumers especially generation $Y$ that made up most of the Malaysian population on financial education and makes it as formal education in the educational system in Malaysia.

More studies need to be done to establish which variables are the most significant predictors that can affect an individual to develop into compulsive buying behaviour. Since this study has discovered the effect of personality traits (Big-Five), materialism and stress on compulsive buying behaviour, future research might explore based on the Social Learning Theory, affluenza or sociocultural context which can affect compulsive buying behaviour. 
INTERNATIONAL JOURNAL OF ACADEMIC RESEARCH IN BUSINESS AND SOCIAL SCIENCES

Vol. 8, No. 7, July 2018, E-ISSN: 2222-6990 @ 2018 HRMARS

\section{Acknowledgement}

We would like to thank the students and staff of Universiti Putra Malaysia and Universiti Malaya who have helped and participated in our data collection process.

\section{Corresponding Author}

Fatin Farwizah binti Mat Rahim

Department of Resource Management and Consumer Studies,

Faculty of Human Ecology,

Universiti Putra Malaysia,

43400 UPM Serdang,

Selangor, Malaysia.

Email: farwizah.fatin@yahoo.com

\section{References}

Al-Dubai, S. A. R., Al-Shagga, M. A., Rampal, K. G., \& Sulaiman, N. A. (2012). Factor structure and reliability of the Malay version of the perceived stress scale among Malaysian medical students. Malays Journal of Medical Science, 19(3), 43-49.

Baldasaro, R. E., Shanahan, M. J., \& Bauer, D. J. (2013). Psychometric properties of the mini-IPIP in a large, nationally representative sample of young adults. Journal of Personality Assessment, 95(1), 74-84.

Bindah, E. V. \& Othman, M. N. (2012). The tantalizing factors associated with compulsive buying among young adult consumers. International Business and Management, 4(2), 16-27.

Black, D. W., Shaw, M., \& Blum, N. (2010). Patholgical gambling and compulsive buying: Do they fall within an obsessive-compulsive spectrum? Dialogues in Clinical Neuroscience, 12(2), 175-185.

Boundy, D. (2000). When Money is the Drug. In A. L. Benson (Ed.), I Shop, Therefore I am: Compulsive Buying and the Search for Self. Northvale, NJ: Jason Aronson Inc.

Cavanaugh, J. C. \& Blanchard - Fields, F. (2011). Adult Development and Aging (6th ed.). Wadsworth: Cengage Learning.

Costa, P. T. \& McCrae, R. R. (1992). NEO-PI-R. The Revised NEO Personality Inventory. Odessa, FL: Psychological Assessment Resources.

Dittmar, H. (2004). Understanding and diagnosing compulsive buying, in R Coombs (Ed.), Handbook of addictive disorders: A practical guide to diagnosis and treatment, (pp. 411-450). Wiley, New York.

Duffy, C. J., Cunningham, E. G., \& Moore, S. M. (2005). The factor structure of mood states in an early adolescent sample. Journal of Adolescence, 28, 677-680.

Durante, K. M. \& Laran, J. (2016). The effect of stress on consumer saving and spending. Journal of Marketing Research, LIII, 814-828.

Gohary, A. \& Hanzaee, K. H. (2014). Personality traits as predictors of shopping motivations and behaviors: A canonical correlation analysis. Arab Economics and Business Journal, 9, 166-174.

Gurau, C. (2012). A life-stage analysis of consumer loyalty profile: Comparing generation $X$ and millennial consumers. Journal of Consumer and Marketing, 29(2), 103-113.

Harvanko, A., Lust, K., Odlaug, B. L., Schreiber, L., Derbyshire, K., Christenson, G., \& Grant, J. E. (2013). Prevalence and characteristics of compulsive buying in college students. Psychiatry Research, 210, 1079-1085. 
INTERNATIONAL JOURNAL OF ACADEMIC RESEARCH IN BUSINESS AND SOCIAL SCIENCES Vol. 8, No. 7, July 2018, E-ISSN: 2222-6990 @ 2018 HRMARS

Hussain, R. \& Ali, M. (2015). Effect of store atmosphere on consumer purchase intention. International Journal of Marketing Studies, 7(2), 35-43.

Joshanloo, M., Rastegar, P., \& Bakhshi, A. (2012). The big five personality domains as predictors of social wellbeing in Iranian university students. Journal of Social and Personal Relationships, 29(5), 639-660.

Lawrence, L. M., Ciorciari, J., \& Kyrios, M. (2014). Relationships that compulsive buying has with addiction, obsessive-compulsiveness, hoarding, and depression. Journal of Comprehensive Psychiatry, 55, 1137-1145.

Lazarus, R. S., \& Folkman, S. (1984). Stress, Coping, and Adaptation. New York: Springer.

Koran, L., Faber, R. J., Aboujaoude, E., Large, M. D., \& Serpe, R. T. (2006). Estimated prevalence of compulsive buying behavior in the United States. American Journal of Psychiatry, 163(1), 1806-1812.

Maltby, J., Day, L., \& Macaskill, A. (2010). Personality, Individual Differences and Intelligence. Essex: Pearson.

Maraz, A., Eisinger, A., Hende, B., Urban, R., Paksi, B., Kun, B., Kokonyei, G., Griffiths, M. D., \& Demetrovics, Z. (2015). Measuring compulsive buying behaviour: Psychometric validity of three different scales and prevalence in the general population and in shopping centres. Journal of Psychiatry Research, 225, 326-334.

Milfont, T. L. \& Sibley, C. G. (2012). The big five personality traits and environmental engagement: Associations at the individual and societal level. Journal of Environmental Psychology, 32, 187195.

Miltenberger, R. G., Redlin, J., Crosby, R., Stickney, M., Mitchell, J., Wonderlich, S., Faber, R., \& Smyth, J. (2003). Direct and retrospective assessment of factors contributing to compulsive buying. Journal of Behavior Therapy and Experimental Psychiatry, 34, 1-9.

Mueller, A., Mitchell, J. E., Peterson, L. A., Faber, R. J., Steffen, K. J., Crosby, R. D., \& Claes, L. (2011). Depression, materialism, and excessive Internet use in relation to compulsive buying. Journal of Comprehensive Psychiatry, 52, 420-424.

Muller, A., Mitchell, J. E., \& Zwann, M. D. (2015). Compulsive buying. The American Journal on Addictions, 24, 132-137.

O'Guinn, T. C. \& Faber, R. J. (1989). Compulsive buying: A phenomenological exploration. Journal of Consumer Research, 16(2), 147-157.

Omar, N. A., Wel, C. A. C., Alam, S. S., \& Nazri, M. A. (2015). Understanding students' compulsive buying of apparel: An empirical study. Jurnal Personalia Pelajar, 18(2), 107-113.

Osman, S., Ong, F. M., Othman, M. N., \& Khong, K. W. (2014). The mediating effect of mood on instore behaviour among Muslim shoppers. Journal of Islamic Marketing, 5(2), 178-197.

Otero-Lopez, J. M. \& Villardefrancos, E. (2013). Five-Factor Model personality traits, materialism, and excessive buying: A mediational analysis. Journal of Personality and Individual Differences, 54, 767-772.

Pallant, J. (2011). SPSS Survival Manual (4 ${ }^{\text {th }}$ Ed.). NSW, Australia: Allen \& Unwin.

Pidgeon, A. M., Bottomley, L., \& Bannatyne, A. (2015). Shop 'til you drop: A coping mechanism for stressed university students? International Journal of Business, Humanities and Technology, 5(3), 28-37.

Quoquab, F., Yasin, N. M., \& Banu, S. (2013). Compulsive buying behavior among young Malaysian consumers. World Review of Business Research, 3(2), 141-154. 
INTERNATIONAL JOURNAL OF ACADEMIC RESEARCH IN BUSINESS AND SOCIAL SCIENCES

Vol. 8, No. 7, July 2018, E-ISSN: 2222-6990 @ 2018 HRMARS

Rasool, S., Kiyani, A., Khattak, J. K., Ahmed, A., \& Ahmed, M. M. (2012). The impact of materialism on compulsive consumption in Pakistan. African Journal of Business Management, 6(49), 1180911818.

Richins, M. L. \& Dawson, S. (1992). A consumer values orientation for materialism and its measurement: Scale development and validation. Journal of Consumer Research, 19, 303-316.

Richins, M. L. (2004). The material values scale: Measurement properties and development of a short form. Journal of Consumer Research, 31(1), 209-219.

Ridgway, N. M., Kukar-Kinney, M., \& Monroe, K. B. (2006). New perspectives on compulsive buying: Its roots, measurement and physiology. Advances in Consumer Research, 33(1), 131-133.

Roberts, J. A. \& Roberts, C. (2012). Stress, gender and compulsive buying among early adolescents. Journal of Young Consumers, 13(2), $113-123$.

Shahjehan, A., Qureshi, J. A., Zeb, F., \& Saifullah, A. (2012). The effect of personality on impulsive and compulsive buying behaviors. African Journal of Business Management, 6(6), 2187-2194.

Shehzadi, K., Ahmad-ur-Rehman, M., Cheema, A. M., \& Ahkam, A. (2016). Impact of personality traits on compulsive buying behavior: Mediating role of impulsive buying. Journal of Service Science and Management, 9, 416-432.

Shrum, L. J., Wong, N., Arif, F., Chugani, S. K., Gunz, A., Lowrey, T. M., Nairn, A., Pandelaere, M., Ross, S. M., Ruvio, A., Scott, K., \& Sundie, J. (2013). Reconceptualizing materialism as identity goal pursuits: Functions, processes, and consequences. Journal of Business Research, 66, 11791185.

Tsang, J., Carpenter, T. P., Roberts, J. A., Frisch, M. B., \& Carlisle, R. D. (2014). Why are materialists less happy? The role of gratitude and need satisfaction in the relationship between materialism and life satisfaction. Personality and Individual Differences, 64, 62-66.

Twenge, J. M. \& Kasser, T. (2013). Generational changes in materialism and work centrality, 19762007: Associations with temporal changes in societal insecurity and materialistic role modelling. Personality and Social Psychology Bulletin, 39(7), 1-15.

Veblen, T. (1994). The Theory of the Leisure Class: An Economic Study in the Evolution of Institutions. New York: Dover.

Veena, N. \& Shastri, S. (2016). Stress and academic performance. The International Journal of Indian Psychology, 3(3), 71-82.

Zamzamin, Z., Jaini, A., \& Mat Zaib, S. Z. (2015). Bankruptcy among young users of credit card in Malaysia: A case study of RHB Islamic (Menara Yayasan Tun Razak) bank customers. In: The Proceedings of the 4th International Seminar on Entrepreneurship and Business (ISEB 2015). Faculty of Entrepreneurship and Business, UMK, 628-636. 